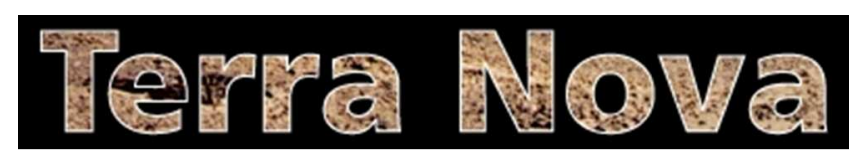

\title{
Direct dating of mid-crustal shear zones with synkinematic allanite: New in-situ U-Th-Pb geochronological approaches applied to the Mont Blanc massif
}

\begin{tabular}{|r|l|}
\hline Journal: & Terra Nova \\
\hline Manuscript ID: & TER-2012-0113.R2 \\
\hline Date Submitted by the Author: & n/a \\
\hline Complete List of Authors: & $\begin{array}{l}\text { Cenki-Tok, Bénédicte; Géosciences Montpellier, } \\
\text { Darling, James; University of Portsmouth, } \\
\text { Rolland, Yann; Géosciences Azur, } \\
\text { Dhuime, Bruno; University of Bristol, } \\
\text { Storey, Craig; University of Portsmouth, }\end{array}$ \\
\hline Keywords: & allanite, U-Th-Pb geochronology, shear zones, Mont Blanc massif \\
\hline
\end{tabular}


1 Direct dating of mid-crustal shear zones with synkinematic allanite: New in situ

2 U-Th-Pb geochronological approaches applied to the Mont Blanc massif

3 Bénédicte Cenki-Tok ${ }^{1,2^{*}}$, James R. Darling ${ }^{3,4^{*}}$, Yann Rolland ${ }^{5}$, Bruno Dhuime ${ }^{6}$, and Craig D. Storey ${ }^{4}$

$4{ }^{1}$ Université Montpellier 2, Géosciences Montpellier, UMR5243, Place Eugène Bataillon, 34095

$5 \quad$ Montpellier

$6{ }^{2}$ Institute of Geological Sciences, Baltzerstrasse 1+3, University of Bern, CH-3012 Bern, Switzerland

$7{ }^{3}$ Department of Earth Sciences, University of Western Ontario, 1151 Richmond Street North, London,

8 Ontario, Canada, N6A 5B7

$9{ }^{4}$ Crustal Evolution Research Group, School of Earth and Environmental Sciences, University of 10 Portsmouth, Burnaby Building, Burnaby Road, Portsmouth, PO1 3QL, UK

$11{ }^{5}$ Géoazur, UMR 7329, Université de Nice Sophia Antipolis, CNRS, IRD, 28 Av. de Valrose, BP 12 2135, 06108 Nice, France.

$13{ }^{6}$ Department of Earth Sciences, University of Bristol, Wills Memorial Building, Queen's Road, Bristol 14 BS8 1RJ, UK

$15 *$ Correspondence: benedicte.cenki-tok@gm.univ-montp2.fr or james.darling@port.ac.uk

\section{ABSTRACT}

Dating the timing of motion on crustal shear zones is of tremendous importance for understanding the assembly of orogenic terranes. This objective is achieved in this paper by combining petrological and structural observations with novel developments in in situ U-Th-Pb geochronology of allanite. A greenschist facies shear zone within the Mont Blanc Massif is documented. Allanite is synkinematic and belongs to the mylonitic assemblage. LA-ICP-MS U-Th-Pb isotope analyses of allanite reveal high contents and highly radiogenic isotopic compositions of the common- $\mathrm{Pb}$ component. The use of measured $\mathrm{Pb}$-isotope compositions of associated minerals (feldspars and chlorite) is critical for 
accurate common- $\mathrm{Pb}$ correction, and provides a powerful mechanism for linking allanite growth to the metamorphic assemblage. A mean ${ }^{208} \mathrm{~Pb} /{ }^{232} \mathrm{Th}$ age of $29.44 \pm 0.95 \mathrm{Ma}$ is accordingly taken for synkinematic allanite crystallisation under greenschist facies conditions. This age reflects the timing of the Mont Blanc underthrusting below the Penninic Front and highlights the potential of directly dating deformation with allanite.

\section{Introduction}

Resolving the timing and rates of crustal deformation is fundamental to our understanding of tectonic and orogenic processes. Direct dating of deformation features by isotopic techniques has great potential to provide new insights into the complexities of orogenesis and tectonics in general. Of particular interest are shear zones, which can accommodate vast lateral and vertical crustal motions, control the development of tectonic features, and provide important pathways for orogenic and oreforming fluids.

In contrast to constraining deformation ages through cross-cutting structural relationships, the direct-dating approach focuses upon isotopic analysis of synkinematic minerals that belong to the metamorphic assemblage associated with deformation. Previous efforts at directly dating deformation focused upon $\mathrm{Rb}-\mathrm{Sr}$ dating of high $\mathrm{Rb} / \mathrm{Sr}$ phases (e.g. Freeman et al., 1997) and ${ }^{40} \mathrm{Ar} /{ }^{39} \mathrm{Ar}$ dating of white mica, amphibole and feldspar (e.g. Simon-Labric et al., 2009). In situ ${ }^{40} \mathrm{Ar} /{ }^{39} \mathrm{Ar}$ dating of recrystallised micas by laser-heating techniques has successfully been applied to mylonites in low temperature conditions, but potential cm-scale mobility of $\mathrm{Ar}$ and excess-Ar may compromise successful thermochronology (Kelley, 2002, Mulch et al., 2005). Texturally controlled Rb-Sr dating also has great potential, but is prone to resetting by post deformation fluid circulation (e.g. Wickman et al., 1983) and isotopic disequilibrium on the thin-section scale (Frey et al., 1976).

Uranium and thorium rich accessory phases, such as zircon and monazite, provide robust ages in many geological settings. Although mechanical modification of zircons in shear zones is relatively common, chemical modifications, and hence age resetting, are not (e.g. Wayne and Sinha, 1992, Moser et al., 2009). To a lesser extent, U-Pb techniques have been successfully applied to dynamically 
recrystallised titanite and monazite (Resor et al., 1996; Storey et al., 2004). Another accessory phase that is a prime target for geochronology in these environments is allanite, which is a rare earth element (REE) rich end-member of the epidote solid solution series ([Ca,REE,Th $\left.]_{2}\left[\mathrm{Fe}, \mathrm{Al}_{3}\right]_{3} \mathrm{Si}_{3} \mathrm{O}_{12}[\mathrm{OH}]\right)$. The mineral is key to the storage and mobility of REE, Th and U (Hermann, 2002, Giéré and Sorensen, 2004), and offers geochronological information that can be linked with physico-chemical conditions (e.g., pressure, temperature conditions), based upon petrological observations. Allanite is also commonly found associated to monazite (Janots et al., 2008). Epidote and clinozoisite generally surround allanite. As thermodynamic stabilities of these phases can be calculated, it is possible to make quantitative links between the timing of monazite/allanite/clinozoisite/epidote growth and $P T$ conditions (e.g. Smye et al., 2010).

A number of studies have reported on the textural and chemical relationships of allanite to rockforming minerals, and on evidence of its stability in $P T$-space (Gregory et al., 2009; Hermann, 2002; Janots et al., 2008; Gregory et al., 2012). Recent advances in allanite in situ U-Th-Pb dating yield reliable ages, despite the fact that allanite contains significant amounts of common $\mathrm{Pb}$ (Gregory et al., 2007; Smith et al., 2009; Darling et al., 2012a). Whereas the petrology and geochemistry of allanite have been addressed repeatedly, little is known so far regarding the effects of deformation and recrystallization on allanite U-Th-Pb systematics (Cenki-Tok et al., 2011).

Accordingly, we have investigated allanite-bearing samples from a greenschist facies shear zone of the Mont Blanc massif (MBM). The principal aims of this study are to: (a) investigate U-Th-Pb isotope systematics of synkinematic allanite using newly developed methods, taking into account the common-Pb composition reflecting the crystallization environment; (b) test whether allanite may be used to directly date the age of deformation and metasomatism.

\section{Geological setting of the Mont Blanc shear zones}

The MBM belongs to a suite of Variscan external crystalline massifs of the western Alps (Fig. 1). It is composed of gneisses and a granitic batholith that crystallized at $300 \pm 3$ Ma (Bussy and von Raumer, 1994). The general deformation pattern of the MBM consists of subvertical narrow (1 to 50 
m) shear zones, arranged in a fan-like geometry, separated by low strain domains (100 to $500 \mathrm{~m}$ ). Deformation, strain localization and associated upper greenschist facies metamorphism in the MBM have been considered Alpine in age (Rolland et al., 2008).

The majority of shear zones are transpressive and form a complex network of anastomosing NNESSW (N40-60 $\left.{ }^{\circ} \mathrm{E}\right)$ and N-S (N160-20 $\left.{ }^{\circ} \mathrm{E}\right)$ components with sub-vertical stretching lineations (Fig. 1). These two groups of shear zones have a dextral and sinistral component, respectively, resulting in a NW-SE compression regime (Rossi et al., 2005). In addition, domains of distinct mineral assemblages within shear zones can be recognized with an NW to SE zoning (Fig. 1). In the NW part, the dominant assemblage is epidote, quartz and muscovite, in the central part, phlogopite, chlorite and quartz are present, and in the SE part, phengite dominates.

\section{Microstructure and petrology of the sample}

This study focuses on a greenschist facies shear zone in the chlorite- and phlogopite-bearing domain (central domain of Fig. 1). This shear zone may be observed along-strike inside the Mont Blanc tunnel, emphasizing its regional 2-dimensional exposure. Lineations are subvertical and shear sense indicators reflect exclusively pure shear: i.e. horizontal shortening. The main mylonitic foliation is marked by chlorite, elongated K-feldspars and recrystallised quartz. Locally, phlogopite is present as larger crystals, and albite crystals occur in low strain parts of the sections of the shear zone. Thermodynamic phase equilibria indicate that shear zone recrystallisation occured at $0.51 \pm 0.05 \mathrm{GPa}$ and $400 \pm 25^{\circ} \mathrm{C}$ (Rolland et al., 2003).

The contact between high-strain domains and low-strain granite pods is anastomosing and fingerlike. In addition, a low Fe-content of fabric minerals is associated to high bulk-rock $\mathrm{Mg} /(\mathrm{Mg}+\mathrm{Fe})$ values compared to the unaltered, undeformed granite. These evidence suggest a localized fluid alteration front associated with greenschist facies metamorphism. These are Mg-rich fluids percolating upwards in the core of the MBM, with high fluid/rock ratios (Rossi et al., 2005).

Small $(<100 \mu \mathrm{m})$, newly crystallised REE-rich phases are parallel to, or occasionally overgrow, the main greenschist facies mylonitic foliation (Fig. 2). New aeschynite and elongate allanite crystals 
102 are idioblastic and contain chlorite, albite and uraninite inclusions. In addition, there are clear 103 differences in zoning, texture, composition and REE patterns between allanite in the host granite and 104 in the shear zone (Rolland et al., 2003), with the shear zone grains being homogeneous in major and 105 REE elements composition (Fig. 3). These observations indicate that, texturally, allanite is not 106 inherited, is in equilibrium with the mylonitic assemblage and therefore synkinematic.

\section{Allanite dating methods}

Laser ablation (LA)-ICP-MS U-Th-Pb isotope analyses were undertaken at the University of Portsmouth, using a New Wave $213 \mathrm{~nm}$ Nd:YAG laser coupled with an Agilent 7500cs ICP-MS. Analytical protocols and instrument conditions are described in detail by Darling et al. (2012a). Key points of the methodology are: (a) line-raster ablation, in order to minimize time-dependent elemental fractionation; (b) external normalisation to the zircon standard Plešovice (Slama et al, 2008); (c) the use of measured ${ }^{204} \mathrm{~Pb}$ to correct for inherited common- $\mathrm{Pb}$. Accuracy was monitored via analyses of the allanite reference materials Tara, Mucrone, BONA and SISS (von Blanckenburg, 1992; Gregory et al., 2007; Cenki-Tok et al., 2011), for each of which mean common- $\mathrm{Pb}$ corrected ${ }^{208} \mathrm{~Pb} /{ }^{232} \mathrm{Th}$ ages are within uncertainty of reference values, with uncertainties of 0.5 to 1.5 percent ( $2 \sigma$; Table 1 ).

$\mathrm{Pb}$-isotope measurements of albite and chlorite were undertaken in a polished block of the studied sample at the University of Bristol, using a New Wave Research $193 \mathrm{~nm}$ ArF Excimer laser coupled with a ThermoFinnigan Neptune multi-collector (MC)-ICP-MS. Analytical procedures followed those of Foster and Vance (2006) and Darling et al. (2012b). Sample measurements were normalised to the NIST 610 glass standard, and NIST 612 was used to monitor accuracy and precision, yielding mean ${ }^{206} \mathrm{~Pb} /{ }^{204} \mathrm{~Pb},{ }^{207} \mathrm{~Pb} /{ }^{204} \mathrm{~Pb}$ and ${ }^{208} \mathrm{~Pb} /{ }^{204} \mathrm{~Pb}$ values of $17.105 \pm 0.008,15.521 \pm 0.006$, and $37.035 \pm 0.013$ respectively (120 $\mu \mathrm{m}$ nominal beam diameter; $\mathrm{n}=12$; all uncertainties $2 \sigma)$.

\section{Allanite U-Th-Pb systematics}

The results of allanite analyses are detailed in Table 2, and key points are summarised in Figure 4. The measured grains typically have high common- $\mathrm{Pb}$ contents, with measured ${ }^{206} \mathrm{~Pb} /{ }^{204} \mathrm{~Pb}$ and 
${ }^{208} \mathrm{~Pb} /{ }^{204} \mathrm{~Pb}$ varying from $32-184$ and $60-474$ respectively. A Tera-Wasserburg type concordia plot (Figure 4A) highlights the dominance of common- $\mathrm{Pb}$. The regression has a poorly defined lower intercept of $21 \pm 18 \mathrm{Ma}$ (all uncertainties $2 \sigma$, unless otherwise stated), but interestingly has a very low y-intercept $(0.41 \pm 0.02)$, which reflects the ${ }^{207} \mathrm{~Pb} /{ }^{206} \mathrm{~Pb}$ composition of the common- $\mathrm{Pb}$ component (Tera and Wasserburg, 1972). This value is far removed from model terrestrial $\mathrm{Pb}$ isotope evolution curves (total ${ }^{207} \mathrm{~Pb} /{ }^{206} \mathrm{~Pb}$ range 0.84 to 1.11 ; Stacey and Kramers, 1975).

The isotopic composition of common- $\mathrm{Pb}$ in the metamorphic assemblage associated with allanite was further investigated via LA-MC-ICP-MS Pb isotope measurements of albite and chlorite from the same sample (Table 3). The measured albite crystals have highly radiogenic age-corrected $\mathrm{Pb}$-isotope values, with weighted mean ${ }^{206} \mathrm{~Pb} /{ }^{204} \mathrm{~Pb},{ }^{207} \mathrm{~Pb} /{ }^{204} \mathrm{~Pb}_{\mathrm{i}}$ and ${ }^{208} \mathrm{~Pb} /{ }^{204} \mathrm{~Pb}_{\mathrm{i}}$ values of $29.75 \pm 0.39,16.08 \pm$ 0.12 and $46.05 \pm 0.34$ respectively (Figure 4B). These ratios were age corrected to $28.2 \pm 2.6 \mathrm{Ma}$ (the allanite $\mathrm{Th}-\mathrm{Pb}$ isochron age; Fig. 4C) using measured ${ }^{238} \mathrm{U} /{ }^{204} \mathrm{~Pb}$ and ${ }^{232} \mathrm{Th} /{ }^{204} \mathrm{~Pb}$, although the magnitude of this correction is less than analytical uncertainty in albites due to low ${ }^{238} \mathrm{U} /{ }^{204} \mathrm{~Pb}(<5.1)$ and ${ }^{232} \mathrm{Th} /{ }^{204} \mathrm{~Pb}(<0.11)$. The single measurement of chlorite has ${ }^{206} \mathrm{~Pb} /{ }^{204} \mathrm{~Pb}_{\mathrm{i}},{ }^{207} \mathrm{~Pb} /{ }^{204} \mathrm{~Pb}$ i and ${ }^{208} \mathrm{~Pb} /{ }^{204} \mathrm{~Pb}_{\mathrm{i}}$ values within uncertainty of the albite mean. Two further analyses of chlorite were rejected due to ablation through $\mathrm{Pb}$-rich inclusions and very low $\mathrm{Pb}$ concentration in one case. Importantly, these measured albite and chlorite values are within uncertainty of the initial ${ }^{208} \mathrm{~Pb} /{ }^{204} \mathrm{~Pb}$ and ${ }^{206} \mathrm{~Pb} /{ }^{204} \mathrm{~Pb}$ values provided by the $\mathrm{Th}-\mathrm{Pb}$ and $\mathrm{U}-\mathrm{Pb}$ isochrons (Fig. 4C-D). As suggested by textural and geochemical evidence, this indicates that allanite is in equilibrium with the mylonitic assemblage and offers new opportunities for accurate common- $\mathrm{Pb}$ correction.

Previous studies have advocated the use of assumed common- $\mathrm{Pb}$ compositions taken from model terrestrial Pb-isotope evolution curves (Stacey and Kramers, 1975), in order to correct $\mathrm{Pb}$ isotope signals for common-Pb in magmatic allanite (e.g. Gregory et al., 2007). However, as shown in Figure 4E, $\mathrm{Th} / \mathrm{Pb}$ ages corrected using a Stacey and Kramers (1975) composition are scattered and do not define a single age population. In contrast, when the measured $\mathrm{Pb}$-isotope composition is used for correction, the data define a single age population, with a weighted mean of $29.44 \pm 0.95 \mathrm{Ma}$ (MSWD $=0.85 ; \mathrm{n}=30 ;$ Figure $4 \mathrm{~F}$ ). This value is within uncertainty of the $\mathrm{Th}-\mathrm{Pb}$ isochron age for these data 
$154(28.2 \pm 2.6 \mathrm{Ma}$; Figure 5), which is independent of common-Pb correction. A necessary pre-requisite 155 for this approach is that metamorphic allanite, chlorite and albite have equilibrated in the same 156 common- $\mathrm{Pb}$ reservoir. In this case, this condition is fulfilled as i) allanites contain chlorite and albite 157 inclusions; ii) initial ${ }^{208} \mathrm{~Pb} /{ }^{204} \mathrm{~Pb}$ from the allanite $\mathrm{Th}-\mathrm{Pb}$ isochron $(47.1 \pm 2.3)$ is within error of the 158 measured albite and chlorite values. There is minor variability in the initial $\mathrm{Pb}$-isotope values of matrix phases that is greater than analytical precision. For example ${ }^{206} \mathrm{~Pb} /{ }^{204} \mathrm{~Pb}_{\mathrm{i}}$ in albites range from $29.53 \pm 0.28$ to $30.40 \pm 0.31$. Further analyses are required to test the scale of Pb-isotope heterogeneity in such metamorphic systems, although this range of variability has a minor effect on calculated ages compared to uncertainty in measurement of ${ }^{204} \mathrm{~Pb}$ in this study. In combination, this analysis of $\mathrm{Pb}$ isotope systematics in allanite and other phases of the metamorphic assemblage provides confidence that the weighted-mean ${ }^{208} \mathrm{~Pb} /{ }^{232} \mathrm{Th}$ age represents the best estimate of crystallization age of allanites in the studied sample.

Common $\mathrm{Pb}$ corrected ${ }^{206} \mathrm{~Pb} /{ }^{238} \mathrm{U}$ ages are highly variable, and significantly older than $\mathrm{Th}-\mathrm{Pb}$ ages. The slope of the U-Pb isochron (Fig. 4D) also provides a significantly older age (122 $\pm 32 \mathrm{Ma}$ ). Two lines of evidence suggest that the ${ }^{238} \mathrm{U}_{-}^{206} \mathrm{~Pb}$ system is compromised by excess ${ }^{206} \mathrm{~Pb}$, either from ${ }^{230} \mathrm{Th}$ disequilibrium (e.g. Scharer, 1984; von Blankenburg, 1992), inherited radiogenic $\mathrm{Pb}$ from a U rich precursor (Romer and Siegesmund, 2003), labile ${ }^{206} \mathrm{~Pb}$ from another source, or a combination of these factors: (1) the initial ${ }^{206} \mathrm{~Pb} /{ }^{204} \mathrm{~Pb}$ provided by the $\mathrm{U}-\mathrm{Pb}$ regression is within uncertainty of the composition of albite and chlorite, suggesting variable levels of ${ }^{206} \mathrm{~Pb}$ incorporation into different grains of allanite; (b) the low ${ }^{207} \mathrm{~Pb} /{ }^{206} \mathrm{~Pb}$ intercept of the Tera-Wasserburg regression $(0.41 \pm 0.02)$ compared to the albite-chlorite initial value $(0.540 \pm 0.014)$. Furthermore, there is a positive correlation between the $\mathrm{Th} / \mathrm{U}$ ratios and ${ }^{206} \mathrm{~Pb} /{ }^{238} \mathrm{U}$ ages of the allanite population, which suggests that U-Th fractionation during crystallization of allanite, causing initial ${ }^{230} \mathrm{Th}$ disequilibrium $\left(\mathrm{t}_{1 / 2}=75 \mathrm{kyr}\right.$; e.g. Scharer, 1984; von Blankenburg, 1992), may be the dominant control on excess ${ }^{206} \mathrm{~Pb}$. 
Significant improvement in understanding the petrology and geochemistry of allanite were made in

181 the past decade (e.g. Janots et al., 2008), but the effects of deformation and recrystallization on allanite $\mathrm{U}-\mathrm{Th}-\mathrm{Pb}$ systematics have as yet been little studied. A first attempt to test whether allanite may be used to infer the age of mylonitisation revealed that the mineral can be remarkably resistant to deformation in relatively dry conditions at eclogite facies due to mechanical shielding that prevents chemical equilibration (Cenki-Tok et al., 2011). This study shows that new crystallisation of allanite may occur in shear zones associated to fluid flux, which can efficiently reset $\mathrm{U}-\mathrm{Th}-\mathrm{Pb}$ isotopic ratios. In the studied shear zone, allanite texturally belongs to the greenschist-facies assemblage. As shown by recent studies (e.g. Janots et al., 2008), allanite is expected to be stable at these PT conditions (ca. $0.5 \mathrm{GPa}$ and $400{ }^{\circ} \mathrm{C}$, Rolland et al., 2003).

The U-Th-Pb closure temperature of allanite is estimated to be above $700{ }^{\circ} \mathrm{C}$ (Heaman and Parrish, 1991), because i) allanite has been shown to remain closed to $\mathrm{Pb}$ loss and retain trace element and $\mathrm{Sr}$ $\mathrm{Nd}$ isotope zonation during prolonged magmatic conditions (Oberli et al., 2004; Gregory et al., 2009); ii) in general zoning patterns developed in allanites during prograde metamorphic growth may be retained through peak conditions (Janots et al., 2008). Due to the high closure temperature of allanite, the age of this study is interpreted as a crystallization age that records shear zone activation under greenschist facies conditions.

The allanite U-Th- $\mathrm{Pb}$ in situ isotope data from this study also highlights the importance of using measured $\mathrm{Pb}$-isotope compositions for common- $\mathrm{Pb}$, particularly in metamorphic rocks in which several processes may fractionate $\mathrm{Th} / \mathrm{Pb}, \mathrm{U} / \mathrm{Pb}$ or $\mathrm{Th} / \mathrm{U}$. Measured albite and chlorite indicate that fluids associated with the metasomatic event (Rossi et al., 2005) had highly radiogenic $\mathrm{Pb}$-isotope compositions. Similar fluid compositions have already been recognised in this zone of the MBM (Marshall et al., 1998). These were interpreted as being related to the emplacement of the Penninic Front that tapped fluid from deep crustal and mantle sources (Rossi et al., 2005). Indeed, metasomatised rocks with similar $\delta^{13} \mathrm{C}$ calcite ratios may also be found at the Penninic Front itself 
In summary, the mean Th- $\mathrm{Pb}$ age of $29.4 \pm 1.0 \mathrm{Ma}$ is taken as the crystallisation age of allanites in the studied shear zone, and hence the age of deformation and fluid percolation. In the SE domain of the MBM (Fig. 1), shear zones yielded younger ${ }^{40} \mathrm{Ar}^{-39} \mathrm{Ar}$ crystallization ages (16 Ma; Rolland et al., 2008). The diachroneity revealed by these two studies highlights a succession of previously unrecognized events in the MBM including: i) ductile deformation and fluid percolation at ca. $29 \mathrm{Ma}$ ascribed to activation of the Penninic Front, which is also recognised further to the South in the Pelvoux Massif (Simon-Labric et al. 2009); ii) reactivation of the shear zones at 16-14 Ma is ascribed to the onset of exhumation in relation with the rotation of Apulia (Rolland et al., 2012).

More generally, allanite may be found in a wide variety of lithologies (felsic, pelitic and mafic). It is a petrologically important mineral in greenschist to amphibolite grade rocks typical of the uppermid crust, particularly when found together with monazite. As its closure temperature is well above these moderate mid-crustal temperatures (ca. $700{ }^{\circ} \mathrm{C}$; Oberli, 1994), allanite ages in these environments are likely to record crystallization rather than cooling. Allanite therefore helps us understand the timing and rates of low to medium temperature processes, which are known to be difficult to date.

\section{Acknowledgements}

BCT thanks M. Engi and M. Rossi for discussion. Financial support from Swiss National Fund (Grants 200020-109637, 200021-117996/1, 200021-103479/1) is gratefully acknowledged. We thank

C. Hetherington and two anonymous reviewers for their constructive comments as well as Klaus Mezger for editorial handling.

\section{References}

Bussy, F. and von Raumer, J.F., 1994. U-Pb geochronology of Paleozoic magmatic events in the Mont 
Cenki-Tok, B., Oliot, E., Rubatto, D., Berger, A., Engi M., Janots, E., Thomsen, T.B., Manzotti, P., Regis, D., Spandler, C., Robyr, M., and Goncalves, P., 2011. Preservation of Permian allanite within an Alpine eclogite facies shear zone at Mt Mucrone, Italy: Mechanical and chemical behavior of allanite during mylonitization. Lithos, 125, 40-50.

Darling, J.R., Storey, C.D. and Engi, M., 2012a. Allanite U-Th-Pb geochronology by laser ablation ICP-MS. Chemical Geology, 292-293, 103-115.

Darling, J.R., Storey, C.D., Hawkesworth, C.J. and Lightfoot, P.C., 2012b. In situ Pb isotope analysis of $\mathrm{Fe}-\mathrm{Ni}-\mathrm{Cu}$ sulphides by laser ablation multi-collector ICP-MS: New insights into ore formation in the Sudbury impact melt sheet. Geochimica et Cosmochimica Acta, 99, 1-17.

Foster, G.L. and Vance, D., 2006. Negligible glacial-interglacial variation in continental chemical weathering rates. Nature, 444, 918-921.

Freeman, S.R., Inger, S., Butler, R.W.H., and Cliff, R.A., 1997. Dating deformation using Rb-Sr in white mica. Greenschist facies deformation ages from the Entrelor shear zone, Italian Alps: Tectonics, 16-1, 57-76.

Frey, M., Hunziker, J.C., O’Neil, J.R. and Schwander, H.W., 1976. Equilibrium-disequilibrium relations in the Monte Rosa granite, Western Alps: petrological, $\mathrm{Rb}-\mathrm{Sr}$ and stable isotope data. Contribution to Mineralogy and Petrology, 55, 147-179.

Gieré, R. and Sorensen, S.S., 2004. Allanite and other REE-rich epidote-group minerals. Reviews in Mineralogy and Geochemistry, 56, 431-493.

Gregory, C.J., Rubatto, D., Allen, C.M., Williams, I.S., Hermann, J., and Ireland, T., 2007. Allanite micro-geochronology: A LA-ICP-MS and SHRIMP U-Th-Pb study. Chemical Geology, 245, $162-182$.

Gregory, C.J., Buick, I.S., Hermann, J. and Rubatto, D., 2009. Mineral-scale Trace Element and $\mathrm{UThPb}$ Age Constraints on Metamorphism and Melting during the Petermann Orogeny (Central Australia). Journal of Petrology, 50(2), 251-287. 
257

Gregory, C.J., Rubatto, D., Hermann, J., Berger, A. a,d Engi, M., 2012. Allanite behaviour during incipient melting in the southern Central Alps. Geochimica Cosmochimica Acta, 84, 433-458.

Heaman, L. and R. Parrish, 1991, "U-Pb Geochronology of Accessory Minerals," chapter 3 in L. Heaman and J.N. Ludden, Applications of Radiogenic Isotope Systems to Problems in Geology, Short Course Handbook, v. 19.

Hermann, J., 2002. Allanite: thorium and light rare earth element carrier in subducted crust. Chemical Geology, 192 (3-4).

Jaffey, A., Flynn, K., Glendenin, L., Bentley, W., Essling, A., 1971. Precision Measurement of HalfLives and Specific Activities of 235U and 238U. Phys. Rev. C 4, 1889-1906

Janots, E., Engi, M., Berger, A., Allaz, J., Schwarz, J.-O., and Spandler, C., 2008. Prograde metamorphic sequence of REE minerals in pelitic rocks of the Central Alps: implications for allanite-monazite-xenotime phase relations from 250 to 610 degrees C. Journal of Metamorphic Geology, 26 (5), 509-526.

Kelley, S., 2002. Excess argon in K-Ar and Ar-Ar geochronology. Chemical Geology, 188, 1-22.

Marshall, D., Pfeifer, H.-R., Hunziker, J.C. and Kirschner, D., 1998. A pressure-temperature-time path for the NE Mont-Blanc massif: Fluid-inclusion, isotopic and thermobarometric evidence. European Journal of Mineralogy, 10, 1227-1240.

Moser, D.E., Davis, W.J., Reddy, S.M., Flemming, R.L. and Hart, R.J., 2009. Zircon U-Pb strain chronometry reveals deep impact-triggered flow. Earth and Planetary Sciences Letters, 277, 73-79.

Mulch, A., Cosca, M.A., Andersen, A. and Fiebig, J., 2005. Time scales of deformation and exhumation in extensional detachement systems determined by high-spatial resolution in situ UV-laser ${ }^{40} \mathrm{Ar} /{ }^{39} \mathrm{Ar}$ dating. Earth and Planetary Sciences Letters, 233, 375-390.

Oberli, F., Meier, M., Berger, A., Rosenberg, C., and Giere, R., 2004. U-Th-Pb and Th-230/U-238 disequilibrium isotope systematics: precise accessory mineral chronology and melt evolution tracing in the Alpine Bergell intrusion. Geochimica Cosmochimica Acta, 68, 2543-2560. 
Petrik, I., Broska, I., 1994. Petrology of 2 granite types from the Tribec mountains, western Carpathians - an example of allanite (+ magnetite) versus monazite dichotomy. Geological Journal 29 (1), 59-78.

Resor, P., Chamberlain, K.R., Frost, C.D., Frost, B.R., and Snoke, A.W., 1996. Direct dating of deformation; $\mathrm{U}-\mathrm{Pb}$ age of syndeformational sphene growth in the Proterozoic Laramie Peak shear zone. Geology, 27 (7), 623-626.

Rolland, Y., Cox, S., Boullier, A.-M., Pennacchioni, G., and Mancktelow, N.S., 2003. Rare earth and trace element mobility in mid-crustal shear zones: insights from the Mont Blanc Massif (Western Alps). Earth and Planetary Science Letters, 214, 203-219.

Rolland, Y., Rossi, M., Cox, S.F., Corsini, M., Mancktelow, N., Pennacchioni, G., Fornari, M., and Boullier, A.M., 2008. ${ }^{40} \mathrm{Ar} /{ }^{39} \mathrm{Ar}$ dating of synkinematic white mica: insights from fluid-rock reaction in low-grade shear zones (Mont Blanc Massif) and constraints on timing of deformation in the NW external Alps. Geological Society, London, Special Publications, 299, 293-315.

Rolland, Y., Lardeaux, J.-M. and Jolivet, L., 2012. Deciphering orogenic evolution. Journal of Geodynamics, 56-57, 1-6.

Romer, R. L., and Siegesmund, S., 2003. Why allanite may swindle about its true age. Contributions to Mineralogy and Petrology, 146, 3, 297-307.

Rossi, M., Rolland, Y., Vidal, O. and Cox, S.F., 2005. Geochemical variations and element transfer during shear-zone development and related episyenites at middle crust depths: insights from the Mont Blanc granite (French-Italian Alps). Geological Society, London, Special Publications, 245, 373-396.

Schärer, U., 1984. The effect of initial ${ }^{230} \mathrm{Th}$ disequilibrium on young U-Pb ages: the Makalu case, Himalaya. Earth and Planetary Science Letters, 67, 191-204. 
307

308

309

310

311

312

313

314

315

316

317

318

319

320

321

322

323

324

Simon-Labric, T., Rolland Y., Dumont, T., Heymes, C., Authemayou, M., Corsini, M., and Fornari., M., 2009. ${ }^{40} \mathrm{Ar} /{ }^{39} \mathrm{Ar}$ dating of Penninic Front tectonic displacement (W Alps) during the Lower Oligocene (31-34 Ma). Terra Nova, 21, 127-136.

Slama, J., Košler, J., Condon, D.J., Crowley, J.L., Gerdes, A., Hanchar, J.M., Horstwood, M.S.A., Morris, G.A., Nasdala, L., Norberb, N., Schaltegger, U., Schoene, B., Tubrett, M.N., and Whitehouse, M.J., 2008. Plešovice zircon - A new natural reference material for U-Pb and Hf isotopic microanalysis. Chemical Geology, 249, 1-35.

Smith, M.P., Storey, C., Jeffries, T. and Ryan, C., 2009. In situ U-Pb and trace element analysis of accessory minerals in the Kiruna district, Norrbotten, Sweden: New constraints on the timing and origin of mineralization. Journal of Petrology, 50 (11), 2063-2094.

Smye, A.J., Greenwood, L.V. \& Holland, T.J.B. (2010). Garnet-chloritoid-kyanite assemblages: eclogite facies indicators of subduction constraints in orogenic belts. Journal of Metamorphic Geology, 28, 753-768.

Stacey, J.S., and Kramers, J.D., 1975. Approximation of terrestrial lead isotope evolution by a two stage model. Earth and Planetary Science Letters, 26, 207-221.

Storey, C.D., Brewer, T.S., and Parrish, R.R., 2004. Late-Proterozoic tectonics in northwest Scotland: one contractional orogeny or several?. Precambrian Research, 134, 227-247.

Tera, F., and Wasserburg, G., 1972. U-Th-Pb systematics in three Apollo 14 basalts and the problem of initial $\mathrm{Pb}$ in lunar rocks. Earth and Planetary Science Letters, 14, 281-304.

Wayne, D.M., and Sinha, A.K., 1992. Stability of zircon U-Pb systematics in a greenschist-grade mylonite - An example from the Rockfish valley fault zone, Central Virginia, USA. Journal of Geology, 100 (5), 593-603.

Wickman, F.E., Aberg, G., and Levi, B., 1983. Rb-Sr dating of alteration events in granitoids. Contribution to Mineralogy and Petrology, 83, 358-362. 
331

332

333

334

335

336

337

338

339

340

341

342

343

344

345

346

347

348

349

350

351

352

353

354

355

von Blanckenburg, F., 1992. Combined high-precision chronometry and geochemical tracing using accessory minerals: applied to the Central-Alpine Bergell intrusion (central Europe). Chemical Geology, 100, 19-40.

\section{Figure and table caption :}

Figure 1: Simplified geological map and cross-section (without vertical exaggeration) of the Mont Blanc Massif with main structural features and mineral assemblages (modified from Rolland et al., 2008). UTM Coordinates of studied sample : (WGS84): N5084.005; E343.502.

Figure 2: Plane polarized light microphotographs of allanite crystals within the studied greenschist facies shear zone.

Figure 3: REE versus Al diagram (after Petrík et al., 1995), showing the compositions of allanites measured by electron microprobe in this study.

Figure 4: Allanite U-Th-Pb ICP-MS isotope data for sample C33. (A): Tera-Wasserburg plot of allanite analyses uncorrected for common $\mathrm{Pb}$. (B): Age corrected $\mathrm{Pb}$ isotope compositions of albites and chlorite. (C) Th- $\mathrm{Pb}$ and (D) U-Pb isochron plots for the allanite analyses of this study. A calculated $\mathrm{U}-\mathrm{Pb}$ isochron corresponding to an age of $30 \mathrm{Ma}$, and using the albite and chlorite measured $\mathrm{Pb}$ isotope composition, is also shown in $\mathrm{B}$ for comparison. Data are not corrected for common- $\mathrm{Pb}$. All uncertainties are at the $95 \%$ confidence level. (E)-(F): Common- $\mathrm{Pb}$ corrected $\mathrm{Pb} / \mathrm{Th}$ ages of allanites, showing the importance of using measured $\mathrm{Pb}$ isotope ratios for common $\mathrm{Pb}$ correction.

Table 1: Summary of allanite U-Th-Pb isotope data for reference materials. The reference ages were measured by Thermal Ionisation Mass Spectrometry (TIMS; von Blanckenburg, 1992) or Sensitive High Resolution Ion Microprobe (SHRIMP; Gregory et al., 2007; Cenki-Tok et al., 2011).

Table 2: Allanite U-Th-Pb isotope data for Mont Blanc sample C33 
356 Table 3: Laser ablation MC-ICP-MS Pb isotope data

357

358

359

360 \\ Page 15 of $22 \quad$ For Review Only}


Table 1:Summary of allanite U-Th-Pb isotope data for reference materials

All analyses at the School of Earth and Environmental Science, University of Portsmouth, United Kingdom

\begin{tabular}{|c|c|c|c|c|c|c|c|c|c|c|c|c|c|c|c|c|c|c|c|c|c|}
\hline \multirow[b]{2}{*}{ Material } & \multirow[b]{2}{*}{$\begin{array}{c}\text { No. } \\
\text { analyses }\end{array}$} & \multirow[b]{2}{*}{$\begin{array}{l}\text { Raster } \\
(\mu \mathrm{m})^{1}\end{array}$} & \multirow[b]{2}{*}{$\begin{array}{l}{ }^{206} \mathrm{~Pb} / \\
{ }^{204} \mathrm{~Pb} \\
\end{array}$} & \multirow[b]{2}{*}{10} & \multicolumn{5}{|c|}{ Mean ratios and common- $\mathrm{Pb}$ contents } & \multirow[b]{2}{*}{10} & \multirow[b]{2}{*}{$\begin{array}{c}208 \mathrm{com} \\
\%\end{array}$} & \multirow[b]{2}{*}{$1 \sigma$} & \multicolumn{2}{|c|}{$\begin{array}{l}\text { Tera-Wasserburg } \\
\text { Regression }\end{array}$} & \multicolumn{4}{|c|}{ Mean common- $\mathrm{Pb}$ corrected ages } & \multirow[b]{2}{*}{$\begin{array}{l}\text { Ref. Age } \\
\text { (Ma) }\end{array}$} & \multirow[b]{2}{*}{ Notes } & \multirow[b]{2}{*}{ Ref. } \\
\hline & & & & & $\begin{array}{l}{ }^{208} \mathrm{~Pb} / \\
{ }^{204} \mathrm{~Pb}\end{array}$ & 10 & $\begin{array}{l}{ }^{206} \mathrm{com} \\
\end{array}$ & $1 \sigma$ & $\begin{array}{l}{ }^{207} \mathrm{com} \\
\%{ }^{2}\end{array}$ & & & & $\begin{array}{c}\text { L. } \\
\text { Intercept } \\
(\mathrm{Ma})\end{array}$ & $\begin{array}{c}1 \sigma \\
\text { abs }\end{array}$ & ${ }^{206} \mathrm{~Pb} /$ & $\begin{array}{l}2 \sigma \\
\text { abs }\end{array}$ & $\begin{array}{l}{ }^{208} \mathrm{~Pb} / \\
{ }^{232} \mathrm{Th} \\
\end{array}$ & $\begin{array}{c}2 \sigma \\
\text { abs }\end{array}$ & & & \\
\hline sISS & 4 & $25 \times 40$ & 31 & 2 & 57 & 4 & 59 & 3 & 93 & 4 & 38 & 3 & 48 & 33 & 35.3 & 2.5 & 32.9 & 2.2 & $31.5 \pm 0.35$ & $\begin{array}{c}\text { Large } \\
{ }^{206} \mathrm{~Pb} \\
\text { excess }\end{array}$ & $\begin{array}{c}\text { von } \\
\text { Blanckenburg } \\
\text { (1992) }\end{array}$ \\
\hline BONA & 4 & $25 \times 40$ & 24 & 4 & 219 & 50 & 79 & 14 & 96 & 5 & 18 & 4 & 82 & 25 & 45 & 35 & 31.0 & 0.7 & $30.1 \pm 0.4$ & $\begin{array}{c}\text { Large } \\
{ }_{206} \mathrm{~Pb} \\
\text { excess }\end{array}$ & $\begin{array}{c}\text { von } \\
\text { Blanckenburg } \\
\text { (1992) }\end{array}$ \\
\hline Tara & 6 & $25 \times 40$ & 459 & 625 & 19232 & 32090 & 16 & 15 & 65 & 60 & 1 & 1 & 420 & 14 & 424 & 11 & 416.4 & 3.4 & $414.9 \pm 3.3$ & & $\begin{array}{l}\text { Gregory et al. } \\
(2007)\end{array}$ \\
\hline Mucrone & 4 & $25 \times 40$ & 90 & 40 & 588 & 150 & 23 & 9 & 76 & 8 & 7 & 2 & 265 & 34 & 316 & 55 & 286.6 & 5.5 & $287 \pm 7$ & & $\begin{array}{l}\text { Cenki-Tok et } \\
\text { al. (2011) }\end{array}$ \\
\hline
\end{tabular}




\section{Table 2: Allanite U-Th-Pb isotope data for Mont Blanc sample C33}

All analyses at the School of Earth and Environmental Science, University of Portsmouth, United Kingdom

\begin{tabular}{|c|c|c|c|c|c|c|c|c|c|c|c|c|c|c|c|c|c|c|c|c|c|c|}
\hline \multirow{2}{*}{\multicolumn{2}{|c|}{$\begin{array}{cc}\text { C33 - Mont Blanc } & \text { Raster } \\
\text { Identifier } \quad(\mu \mathrm{m})^{1}\end{array}$}} & & & & \multicolumn{7}{|c|}{ Common- $\mathrm{Pb}$ contents ${ }^{2}$} & \multicolumn{4}{|c|}{ Data for Tera-Wasserburg plot ${ }^{3}$} & \multirow[b]{2}{*}{$\begin{array}{l}{ }^{208} \mathrm{~Pb} / \\
{ }^{206} \mathrm{~Pb}\end{array}$} & \multirow[b]{2}{*}{$\begin{array}{l}{ }^{208} \mathrm{~Pb} / \\
{ }^{232} \mathrm{Th}\end{array}$} & \multirow[b]{2}{*}{$1 \sigma \%$} & \multicolumn{4}{|c|}{ Common-Pb corrected ages } \\
\hline & & $\begin{array}{c}{ }^{204} \mathrm{~Pb} \\
\mathrm{cps}\end{array}$ & $\begin{array}{l}\text { Th } \\
/ U\end{array}$ & $\begin{array}{l}1 \sigma \\
\%\end{array}$ & $\begin{array}{l}{ }^{206} \mathrm{~Pb} \\
/^{204} \mathrm{~Pb}\end{array}$ & $\begin{array}{l}1 \sigma \\
\% \\
\end{array}$ & $\begin{array}{l}{ }^{208} \mathrm{~Pb} / \\
{ }^{204} \mathrm{~Pb}\end{array}$ & $\begin{array}{l}1 \sigma \\
\%\end{array}$ & $\begin{array}{c}{ }^{206} \mathrm{com} \\
\% \\
\end{array}$ & $\begin{array}{c}{ }^{207} \mathrm{com} \\
\% \\
\end{array}$ & $\begin{array}{c}{ }^{208} \mathrm{com} \\
\% \\
\end{array}$ & $\begin{array}{l}{ }^{238} \mathrm{U} / \\
{ }^{206} \mathrm{~Pb}\end{array}$ & $\begin{array}{r}1 \sigma \\
a b s \\
\end{array}$ & $\begin{array}{l}{ }^{207} \mathrm{~Pb} / \\
{ }^{206} \mathrm{~Pb}\end{array}$ & $\begin{array}{c}1 \sigma \\
\text { abs }\end{array}$ & & & & $\begin{array}{l}{ }^{206} \mathrm{~Pb} / \\
{ }^{238} \mathrm{U}\end{array}$ & $\begin{array}{c}2 \sigma \\
\text { abs }\end{array}$ & $\begin{array}{l}{ }^{208} \mathrm{~Pb} / \\
{ }^{232} \mathrm{Th}\end{array}$ & $\begin{array}{l}2 \sigma \\
a b s\end{array}$ \\
\hline Au16C07 & $25 \times 40$ & 81 & 25 & 4 & 43 & 8 & 79 & 8 & 70 & 99 & 58 & 15.4 & 0.5 & 0.37 & 0.02 & 1.8 & 0.0036 & 2.3 & 127 & 36 & 31.3 & 6.5 \\
\hline Au16C08 & $25 \times 40$ & 64 & 16 & 6 & 45 & 7 & 73 & 6 & 67 & 97 & 63 & 16.7 & 1.3 & 0.37 & 0.02 & 1.6 & 0.0049 & 2.9 & 125 & 65 & 37.6 & 9.2 \\
\hline Au16C09 & $25 \times 40$ & 76 & 15 & 7 & 42 & 5 & 70 & 4 & 72 & 96 & 66 & 18.8 & 1.1 & 0.39 & 0.02 & 1.6 & 0.0048 & 3.2 & 97 & 44 & 33.9 & 9.1 \\
\hline Au16C10 & $25 \times 40$ & 85 & 16 & 6 & 41 & 13 & 72 & 10 & 74 & 100 & 64 & 20.4 & 0.5 & 0.39 & 0.01 & 1.7 & 0.0045 & 2.2 & 82 & 23 & 33.1 & 7.5 \\
\hline Au16C11 & $25 \times 40$ & 65 & 35 & 4 & 41 & 13 & 74 & 10 & 73 & 96 & 62 & 12.6 & 0.4 & 0.40 & 0.02 & 1.8 & 0.0036 & 2.5 & 136 & 43 & 28.3 & 6.5 \\
\hline Au16C12 & $25 \times 40$ & 125 & 21 & 5 & 43 & 11 & 70 & 4 & 71 & 99 & 66 & 11.9 & 0.3 & 0.38 & 0.01 & 1.6 & 0.0049 & 1.7 & 158 & 41 & 34.7 & 7.7 \\
\hline Au17c05 & $25 \times 40$ & 45 & 71 & 5 & 48 & 17 & 103 & 8 & 62 & 84 & 45 & 12.7 & 0.5 & 0.40 & 0.03 & 2.1 & 0.0024 & 2.3 & 188 & 54 & 27.1 & 4.3 \\
\hline Au17c06 & $25 \times 40$ & 73 & 36 & 6 & 55 & 16 & 108 & 8 & 55 & 78 & 43 & 20.9 & 0.5 & 0.38 & 0.01 & 1.9 & 0.0027 & 1.5 & 137 & 27 & 31.1 & 4.3 \\
\hline Au17c07 & $25 \times 40$ & 36 & 34 & 4 & 39 & 18 & 70 & 9 & 77 & 100 & 66 & 13.6 & 0.9 & 0.39 & 0.03 & 1.7 & 0.0040 & 3.6 & 111 & 66 & 28.1 & 8.0 \\
\hline Au17c08 & $25 \times 40$ & 15 & 52 & 5 & 184 & 7 & 474 & 5 & 16 & 17 & 10 & 31.5 & 1.9 & 0.39 & 0.03 & 2.5 & 0.0016 & 3.9 & 169 & 26 & 29.5 & 2.7 \\
\hline Au17c09 & $25 \times 40$ & 42 & 62 & 5 & 54 & 11 & 96 & 9 & 56 & 80 & 48 & 10.5 & 0.5 & 0.37 & 0.03 & 1.7 & 0.0028 & 4.0 & 266 & 77 & 29.7 & 6.2 \\
\hline Au17c10 & $25 \times 40$ & 29 & 53 & 5 & 41 & 19 & 87 & 9 & 74 & 94 & 53 & 14.7 & 0.7 & 0.42 & 0.03 & 2.1 & 0.0027 & 3.7 & 114 & 50 & 25.9 & 5.8 \\
\hline Au17c11 & $25 \times 40$ & 19 & 36 & 6 & 72 & 8 & 164 & 6 & 42 & 63 & 28 & 29.2 & 3.6 & 0.35 & 0.02 & 2.2 & 0.0022 & 2.2 & 127 & 56 & 31.7 & 3.3 \\
\hline Au17c12 & $25 \times 40$ & 35 & 64 & 5 & 51 & 13 & 103 & 10 & 59 & 80 & 45 & 13.1 & 0.6 & 0.40 & 0.03 & 2.0 & 0.0025 & 1.9 & 199 & 57 & 27.7 & 4.2 \\
\hline Au17c13 & $25 \times 40$ & 19 & 71 & 5 & 46 & 16 & 108 & 12 & 65 & 79 & 43 & 16.1 & 2.4 & 0.43 & 0.03 & 2.3 & 0.0021 & 7.2 & 140 & 123 & 24.0 & 6.8 \\
\hline Au17c14 & $25 \times 40$ & 81 & 60 & 5 & 54 & 14 & 112 & 7 & 56 & 78 & 41 & 14.0 & 0.4 & 0.38 & 0.02 & 2.0 & 0.0025 & 1.7 & 202 & 42 & 29.9 & 4.1 \\
\hline Au17c15 & $25 \times 40$ & 51 & 32 & 5 & 42 & 14 & 71 & 7 & 71 & 99 & 64 & 15.3 & 0.4 & 0.39 & 0.02 & 1.7 & 0.0035 & 2.3 & 119 & 33 & 25.2 & 5.8 \\
\hline Au17c16 & $25 \times 40$ & 34 & 38 & 5 & 40 & 17 & 73 & 9 & 76 & 100 & 63 & 14.2 & 0.7 & 0.39 & 0.02 & 1.8 & 0.0036 & 3.3 & 110 & 53 & 26.9 & 6.9 \\
\hline Au17d05 & $25 \times 40$ & 58 & 43 & 5 & 39 & 12 & 74 & 6 & 71 & 96 & 57 & 15.0 & 0.4 & 0.39 & 0.02 & 2.0 & 0.0033 & 2.8 & 125 & 35 & 28.9 & 6.1 \\
\hline Au17d06 & $25 \times 40$ & 52 & 63 & 5 & 32 & 18 & 70 & 10 & 77 & 98 & 54 & 13.1 & 0.5 & 0.42 & 0.03 & 2.3 & 0.0030 & 2.1 & 111 & 46 & 27.7 & 5.1 \\
\hline Au17d07 & $25 \times 40$ & 56 & 36 & 6 & 39 & 10 & 72 & 6 & 68 & 84 & 56 & 17.6 & 0.9 & 0.43 & 0.03 & 1.9 & 0.0033 & 2.8 & 117 & 44 & 28.7 & 6.1 \\
\hline Au17d08 & $25 \times 40$ & 15 & 72 & 5 & 98 & 22 & 184 & 16 & 71 & 99 & 48 & 11.3 & 0.6 & 0.38 & 0.02 & 1.9 & 0.0031 & 2.6 & 166 & 66 & 32.9 & 5.7 \\
\hline Fe14d05 & $30 \times 45$ & 121 & 35 & 4 & 39 & 4 & 72 & 2 & 76 & 100 & 64 & 12.0 & 0.3 & 0.41 & 0.01 & 2.1 & 0.0038 & 1.8 & 130 & 39 & 27.5 & 5.9 \\
\hline Fe14d06 & $30 \times 45$ & 199 & 7 & 7 & 43 & 3 & 60 & 2 & 69 & 98 & 76 & 26.1 & 0.7 & 0.37 & 0.02 & 1.6 & 0.0067 & 2.2 & 78 & 20 & 32.1 & 9.4 \\
\hline $\mathrm{Fe} 14 \mathrm{~d} 07$ & $30 \times 45$ & 13 & 24 & 4 & 41 & 17 & 75 & 9 & 72 & 99 & 62 & 19.2 & 1.3 & 0.39 & 0.03 & 2.1 & 0.0034 & 3.7 & 93 & 50 & 26.7 & 7.1 \\
\hline $\mathrm{Fe} 14 \mathrm{~d} 08$ & $30 \times 45$ & 29 & 32 & 5 & 62 & 13 & 127 & 7 & 48 & 69 & 36 & 22.0 & 0.5 & 0.37 & 0.01 & 2.3 & 0.0024 & 1.8 & 152 & 26 & 30.5 & 3.8 \\
\hline Fe14d09 & $30 \times 45$ & 65 & 29 & 5 & 39 & 9 & 65 & 4 & 76 & 99 & 71 & 10.4 & 0.3 & 0.41 & 0.01 & 1.9 & 0.0050 & 2.3 & 148 & 51 & 29.7 & 7.8 \\
\hline Fe14d10 & $30 \times 45$ & 19 & 29 & 5 & 41 & 18 & 71 & 8 & 72 & 99 & 65 & 12.0 & 0.4 & 0.39 & 0.02 & 2.0 & 0.0043 & 2.2 & 150 & 45 & 30.5 & 7.1 \\
\hline Fe14d11 & $30 \times 45$ & 26 & 35 & 6 & 50 & 14 & 89 & 7 & 60 & 95 & 52 & 13.2 & 0.5 & 0.37 & 0.02 & 2.1 & 0.0033 & 2.1 & 192 & 50 & 31.9 & 5.7 \\
\hline Fe14d12 & $30 \times 45$ & 53 & 14 & 4 & 44 & 9 & 73 & 4 & 68 & 96 & 63 & 28.5 & 1.9 & 0.38 & 0.01 & 1.9 & 0.0035 & 2.4 & 71 & 33 & 25.9 & 5.9 \\
\hline
\end{tabular}

1 Nominal beam diameter and line raster length.

${ }^{2}$ Ratio of common- $\mathrm{Pb}$ to total $\mathrm{Pb}$ signal, given as percentage.

${ }_{4}^{3}$ Data not corrected for common-Pb.

Common- $\mathrm{Pb}$ corrected using measured $\mathrm{Pb}$ isotope ratios from feldspars and chlorites.

Decay constants of Jaffey et al (1971) used 


\section{Table 3: Laser ablation MC-ICPMS Pb isotope data}

Analyses at the Department of Earth Sciences, University of Bristol, United Kingdom

\begin{tabular}{|c|c|c|c|c|c|c|c|c|c|c|c|c|c|c|c|c|c|c|c|c|c|c|c|c|}
\hline \multirow[b]{2}{*}{ Identifier } & \multirow[b]{2}{*}{ Phase } & \multirow[b]{2}{*}{$\begin{array}{c}\text { Beam } \\
(\mu \mathrm{m})^{1}\end{array}$} & \multirow[b]{2}{*}{$\begin{array}{l}\mathrm{Pb}_{\text {total }} \\
(\mathrm{V})^{2}\end{array}$} & \multirow[b]{2}{*}{$\begin{array}{l}{ }^{206} \mathrm{~Pb} / \\
{ }^{204} \mathrm{~Pb}\end{array}$} & \multirow[b]{2}{*}{$\begin{array}{c}2 \sigma \\
\text { abs }\end{array}$} & \multirow[b]{2}{*}{$\begin{array}{l}{ }^{207} \mathrm{~Pb} / \\
{ }^{204} \mathrm{~Pb}\end{array}$} & \multicolumn{3}{|c|}{ Measured Ratios } & \multirow[b]{2}{*}{$\begin{array}{l}{ }^{207} \mathrm{~Pb} / \\
{ }^{206} \mathrm{~Pb}\end{array}$} & \multirow[b]{2}{*}{$\begin{array}{l}2 \sigma \\
a b s\end{array}$} & \multirow[b]{2}{*}{$\begin{array}{l}{ }^{208} \mathrm{~Pb} / \\
{ }^{206} \mathrm{~Pb}\end{array}$} & \multirow[b]{2}{*}{$\begin{array}{c}2 \sigma \\
\text { abs }\end{array}$} & \multicolumn{5}{|c|}{ U-Th-Pb data ${ }^{3}$} & \multicolumn{6}{|c|}{ Age corrected ratios ${ }^{4}$} \\
\hline & & & & & & & $\begin{array}{c}2 \sigma \\
\text { abs }\end{array}$ & $\begin{array}{l}{ }^{208} \mathrm{~Pb} / \\
{ }^{204} \mathrm{~Pb}\end{array}$ & $\begin{array}{c}2 \sigma \\
\text { abs }\end{array}$ & & & & & $\begin{array}{c}\mathrm{Pb} \\
(\mathrm{ppm})\end{array}$ & $\begin{array}{l}{ }^{238} \mathrm{U} / \\
{ }^{204} \mathrm{~Pb}\end{array}$ & $\begin{array}{l}2 \sigma \\
a b s\end{array}$ & $\begin{array}{l}{ }^{232} \mathrm{Th} / \\
{ }^{204} \mathrm{~Pb}\end{array}$ & $\begin{array}{c}2 \sigma \\
\text { abs }\end{array}$ & $\begin{array}{l}{ }^{206} \mathrm{~Pb} / \\
{ }^{204} \mathrm{~Pb}\end{array}$ & $\begin{array}{l}2 \sigma \\
\text { abs }\end{array}$ & $\begin{array}{l}{ }^{207} \mathrm{~Pb} / \\
{ }^{204} \mathrm{~Pb}\end{array}$ & $\begin{array}{c}2 \sigma \\
a b s\end{array}$ & $\begin{array}{l}{ }^{208} \mathrm{~Pb} / \\
{ }^{204} \mathrm{~Pb}\end{array}$ & $\begin{array}{l}2 \sigma \\
a b s\end{array}$ \\
\hline C33_01 & Albite & 120 & 0.26 & 29.88 & 0.23 & 16.18 & 0.10 & 46.28 & 0.31 & 0.542 & 0.002 & 1.550 & 0.004 & 1.5 & 5.1 & 0.3 & 0.09 & 0.01 & 29.63 & 0.23 & 16.16 & 0.10 & 46.27 & 0.31 \\
\hline C33_02 & Albite & 120 & 0.26 & 29.92 & 0.23 & 16.11 & 0.12 & 46.18 & 0.34 & 0.539 & 0.002 & 1.544 & 0.003 & 1.7 & 4.1 & 0.2 & 0.10 & 0.01 & 29.72 & 0.23 & 16.10 & 0.12 & 46.18 & 0.34 \\
\hline C33_03 & Albite & 90 & 0.18 & 29.78 & 0.28 & 16.11 & 0.15 & 46.02 & 0.44 & 0.541 & 0.001 & 1.547 & 0.001 & 2.1 & 4.9 & 0.3 & 0.11 & 0.01 & 29.53 & 0.28 & 16.10 & 0.15 & 46.02 & 0.44 \\
\hline C33_04 & Albite & 90 & 0.14 & 29.87 & 0.36 & 15.88 & 0.19 & 45.48 & 0.55 & 0.532 & 0.001 & 1.524 & 0.002 & 2.8 & 5.0 & 0.3 & 0.09 & 0.01 & 29.62 & 0.36 & 15.87 & 0.19 & 45.48 & 0.55 \\
\hline C33_05 & Albite & 120 & 0.22 & 30.64 & 0.31 & 16.03 & 0.14 & 45.82 & 0.41 & 0.523 & 0.002 & 1.497 & 0.004 & 1.6 & 4.9 & 0.3 & 0.10 & 0.01 & 30.40 & 0.31 & 16.02 & 0.14 & 45.82 & 0.41 \\
\hline C33_06 & Chlorite & 120 & 0.18 & 31.65 & 0.39 & 16.20 & 0.19 & 46.65 & 0.56 & 0.512 & 0.001 & 1.475 & 0.002 & 1.1 & 45.0 & 2.6 & 5.00 & 0.28 & 29.43 & 0.39 & 16.09 & 0.19 & 46.57 & 0.56 \\
\hline
\end{tabular}

\section{Nominal beam diameter}

${ }^{2}$ Total $\mathrm{Pb}$ signal in volts, using $10^{11} \Omega$ resistors for all isotopes.

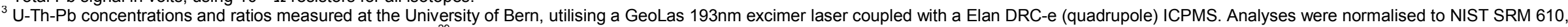
and NIST SRM 612 was used as a consistency standard. ${ }^{29} \mathrm{Si}$ was used as an internal standard.

${ }^{4} \mathrm{~Pb}$ isotope ratios corrected for in-growth of radiogenic $\mathrm{Pb}$ to $30 \mathrm{Ma}$. Note that the magnitude of correction is small compared to analytical uncertainties on $\mathrm{Pb}$ isotope ratio measurements. 


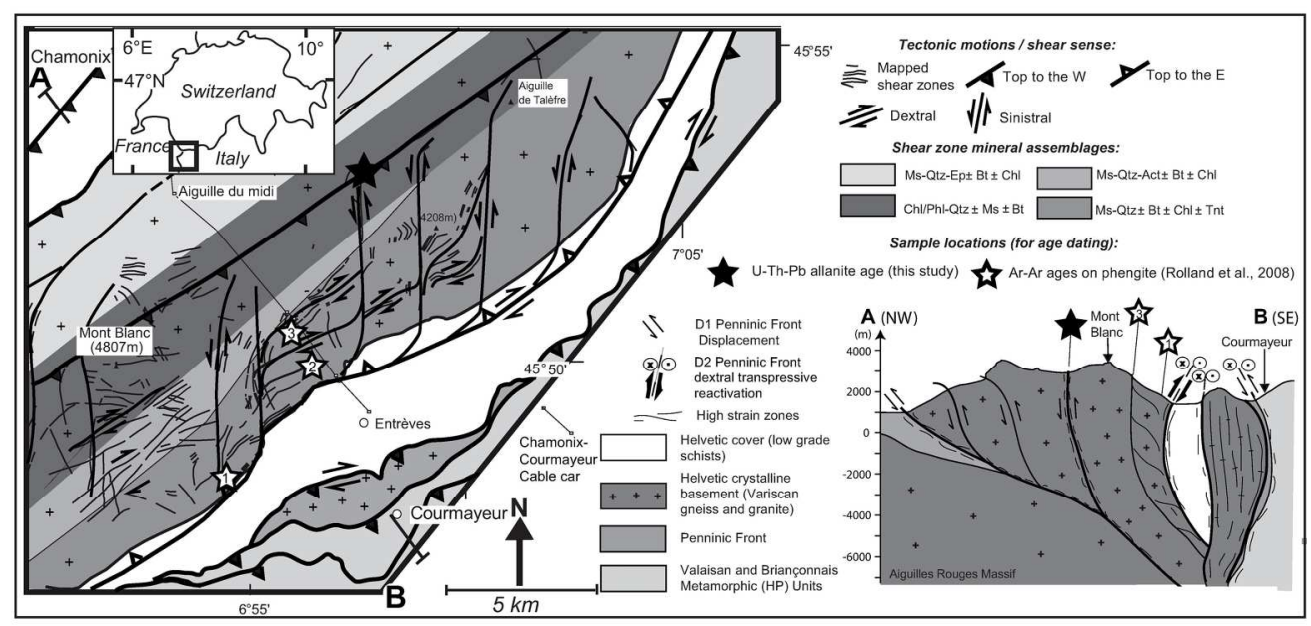

Figure 1: Cenki-Tok et al.

$187 \times 167 \mathrm{~mm}$ ( $300 \times 300$ DPI) 


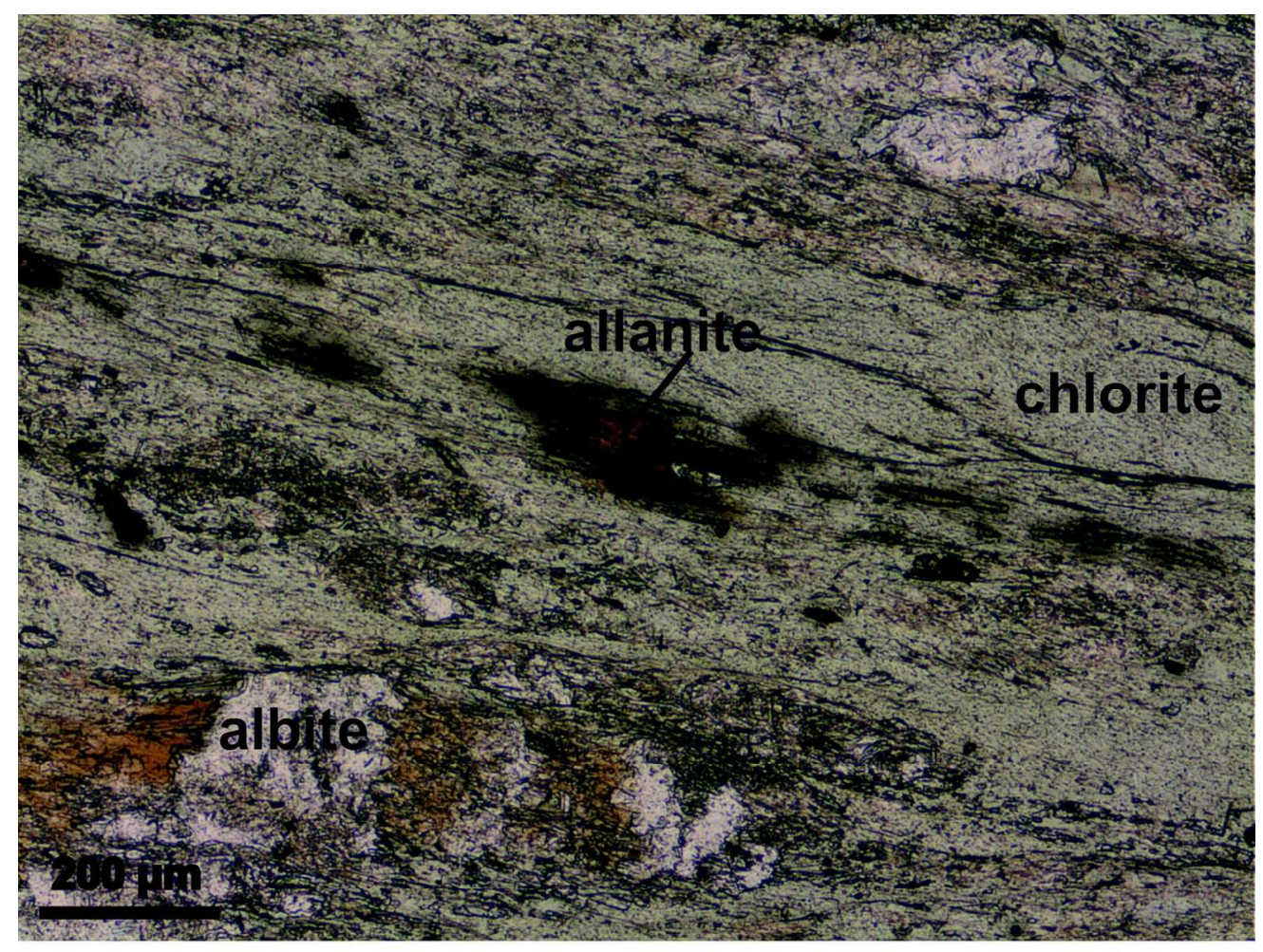

Figure 2: Cenki-Tok et al.

$136 \times 137 \mathrm{~mm}(300 \times 300 \mathrm{DPI})$ 


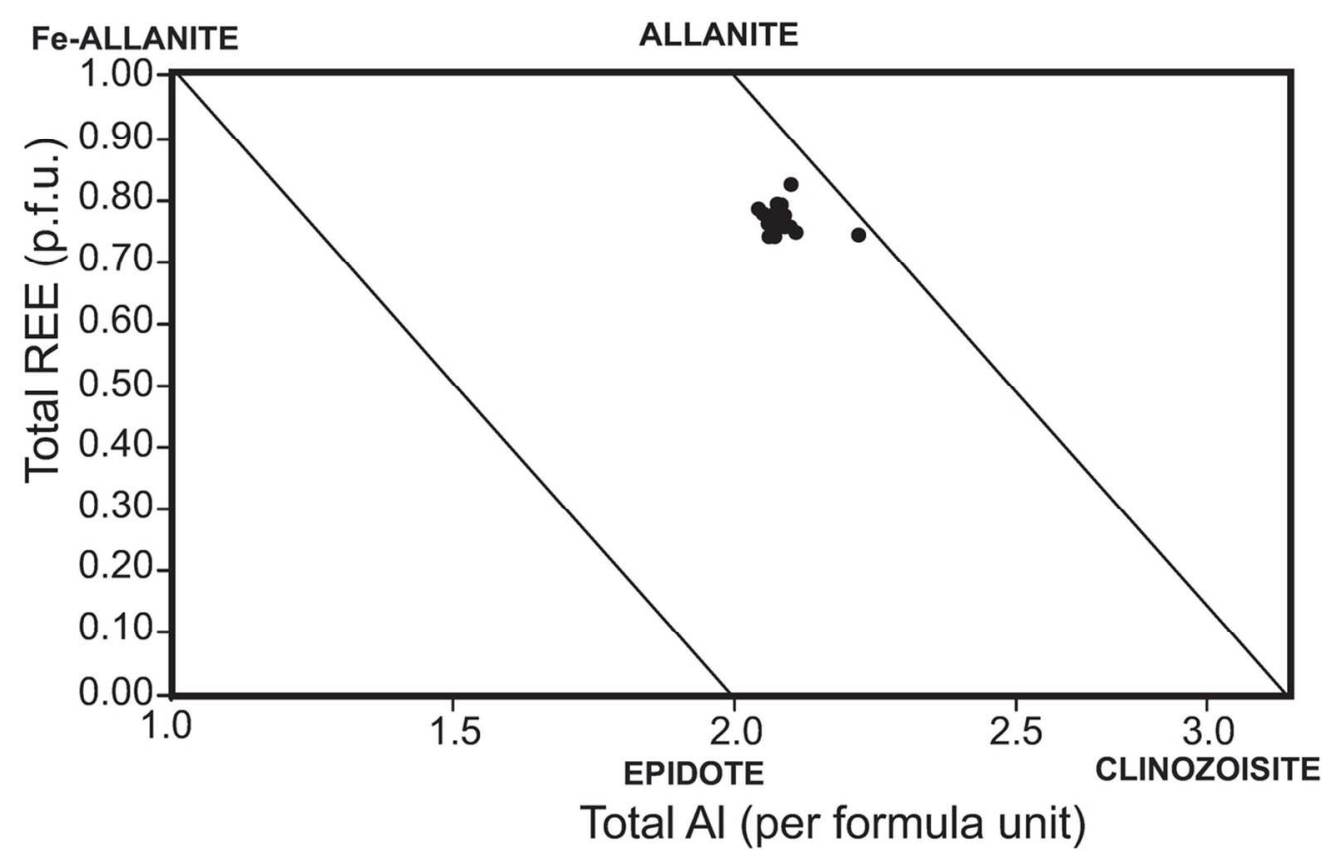

Figure 3: Cenki-Tok et al.

$106 \times 80 \mathrm{~mm}(300 \times 300$ DPI $)$ 
(A)
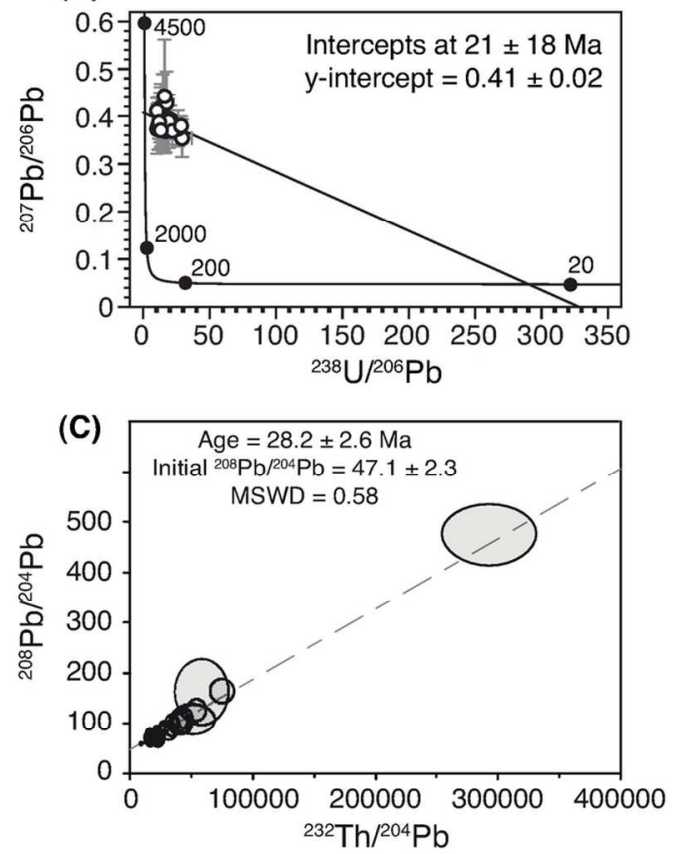

(E) Corrected using S-K model at $30 \mathrm{Ma}^{1}$

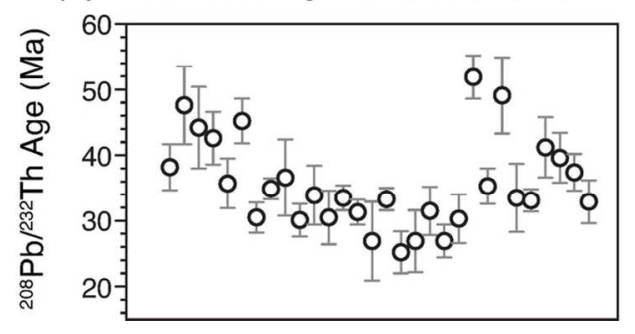

(B)
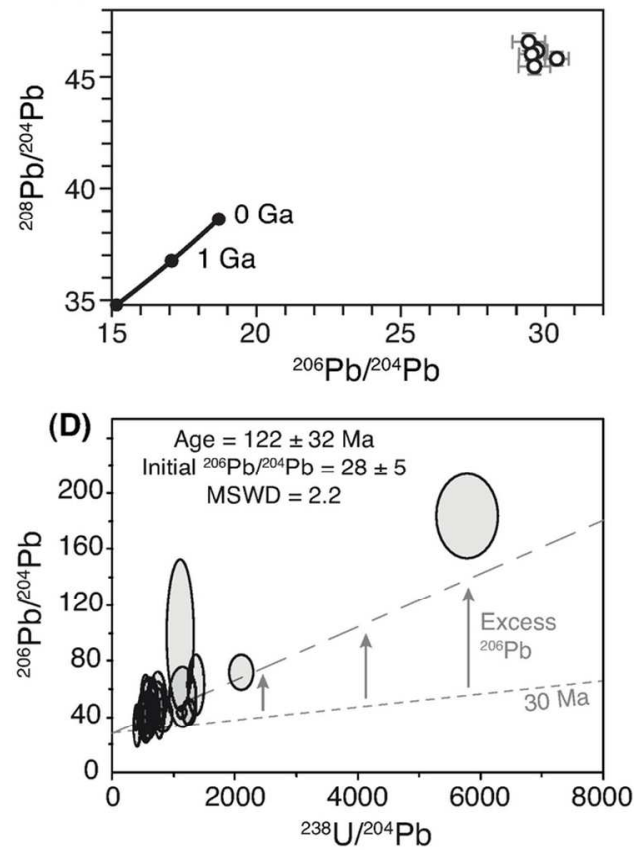

(F) Corrected using measured ratios ${ }^{2}$

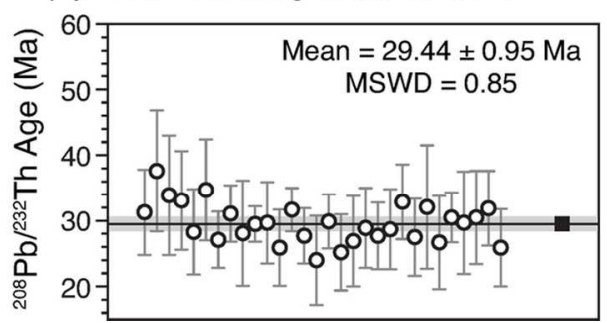

$113 \times 110 \mathrm{~mm}(300 \times 300$ DPI $)$ 